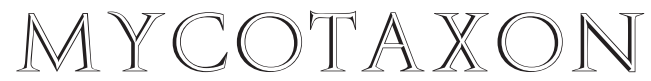

Volume 123, pp. 403-408

http://dx.doi.org/10.5248/123.403

January-March 2013

\title{
Acaulospora endographis (Glomeromycetes), a new fungus with a complex spore wall
}

\author{
Bruno T. Goto ${ }^{1^{*}}$, Camilla M.R. Pereira ${ }^{2}$, Camila P. Nobre 3 , \\ Natalia P. Zatorre ${ }^{3}$, Fernanda Covacevich ${ }^{4}$, \\ RicARDo L.L. BERBARA ${ }^{3} \&$ LEONOR C. MAIA ${ }^{2}$ \\ ${ }^{1}$ Departamento de Botânica, Ecologia e Zoologia, CB, Universidade Federal do \\ Rio Grande do Norte, Campus Universitário, 59072-970, Natal, RN, Brazil \\ ${ }^{2}$ Departamento de Micologia, CCB, Universidade Federal de Pernambuco, \\ Av. Prof. Nelson Chaves, S/N, CEP 50670-420, Cidade Universitária, Recife, PE, Brazil \\ ${ }^{3}$ Departamento de Ciências do Solo, Universidade Federal Rural do Rio de Janeiro, \\ Seropédica, Rio de Janeiro, Brazil \\ ${ }^{4}$ CONICET, Laboratorio de Microbiología de Suelo Estación Experimental Agropecuaria INTA, \\ Balcarce, Argentina \\ “CORRESPONDENCE TO: brunogoto@hotmail.com
}

\begin{abstract}
Aвstract - A new acaulosporoid fungal species characterized by glomerospores with a complex ten-layered wall structure and uniquely ornamented fourth layer (outer wall layer OWL4) found in impacted areas of the Amazon Forest and cultivated areas of the Atlantic Forest in Brazil is described as Acaulospora endographis.
\end{abstract}

Key words - Glomeromycota, Diversisporales, Acaulosporaceae, morphology

\section{Introduction}

Several arbuscular mycorrhizal (AM) fungal species with a generally scutellosporoid spore development have been described from tropical areas (Cuenca \& Herrera-Peraza 2008; Silva et al. 2008; Oehl et al. 2008, Goto et al. 2009, 2010, 2011, 2012; Tchabi et al. 2009). In contrast, only a few species with an acaulosporoid development have been described during the last 10 years from the tropics [Ambispora brasiliensis (Goto et al. 2008), Acaulospora punctata (Oehl et al. 2011a), Ac. sieverdingii (Oehl et al. 2011b), and Ac. soloidea (Vaingankar \& Rodrigues 2011)], with the first two described from South America.

An undescribed ornamented acaulosporoid fungus frequently found during diversity studies of arbuscular mycorrhizal fungi in Brazilian biomes is here described and illustrated as Acaulospora endographis. 


\section{Material \& methods}

\section{Study area and sites}

Soil samples were collected in the Seringal Cachoeira $\left(7^{\circ} 07^{\prime}-11^{\circ} 08^{\prime} S 66^{\circ} 30^{\prime}-74^{\circ} 00^{\prime} \mathrm{W}\right)$, located in the municipality of Xapuri, Acre State, north Brazil. Soils were characterized as red-yellow Argissols (Ultisols). The climate in the region is Am' Equatorial (Köppen classification): hot and humid with $24.5-32^{\circ} \mathrm{C}$ average temperatures with two distinct seasons: dry (300-375 $\mathrm{mm}$ precipitation) and rainy $(1200-1360 \mathrm{~mm})$. The study areas consisted of an open rainforest dominated by palms, a 20 year-old secondary forest, and a 30 year-old regenerated pasture with Brachiaria decumbens Stapf, Bertholletia excelsa Bonpl., and Zea mays L. The soil contained 4.77-3.44 mg. $\mathrm{dm}^{-3}$ organic phosphorus, $0.31-0.21 \mathrm{cmol}_{\mathrm{c}} \cdot \mathrm{kg}^{-1}$ potassium, $6.04-3.78 \mathrm{cmol}_{\mathrm{c}} \cdot \mathrm{kg}^{-1}$ calcium, $2.88-2.62 \mathrm{cmol} \cdot \mathrm{kg}^{-1}$ magnesium, $2.62-2.44 \mathrm{cmol} \cdot \mathrm{kg}^{-1} \mathrm{H}+\mathrm{Al}$, and $41-26 \mathrm{~g} . \mathrm{kg}^{-1}$ organic matter with a $\mathrm{pH}$ of 5.60-5.35. Other soil samples, also characterized as red-yellow Argissols (Ultisols), were collected from the Experimental Station of Itapirema (Instituto Agronômico de Pernambuco) in the municipality of Goiana $\left(7^{\circ} 38^{\prime} 20^{\prime \prime} \mathrm{S} 34^{\circ} 57^{\prime} 10^{\prime \prime} \mathrm{W}\right)$, Pernambuco State, northeast Brazil, where the climate is Ams' (Köppen classification): tropical rainy with $21.1-31.3^{\circ} \mathrm{C}$ average annual temperature and $2000 \mathrm{~mm}$ average annual rainfall. The soil was sampled during the rainy season (June 2011) in an area cultivated for nine months with cassava (Manihot esculenta Crantz); this area was fertilized with NPK and the $\mathrm{pH}$ corrected with calcitic limestone at planting time. The soil composition was 3.8 mg. $\mathrm{dm}^{-3}$ organic phosphorus, $0.006 \mathrm{cmol} \cdot \mathrm{kg}^{-1}$ potassium, $0.005 \mathrm{cmol} \cdot \mathrm{kg}^{-1}$ calcium, $0.003 \mathrm{cmol}_{\mathrm{c}} \mathrm{kg}^{-1}$ magnesium, and $31.0 \mathrm{~g} . \mathrm{kg}^{-1}$ organic matter with a $\mathrm{pH}$ of 5.3 .

\section{Morphological analyses}

Acaulosporoid spores were extracted from field soils and from trap cultures by wet sieving and sucrose centrifugation (Sieverding 1991). The spores were isolated in a stereomicroscope and mounted in polyvinyl alcohol-lacto-glycerin (PVLG) and PVLG + Melzer's reagent (Brundrett et al. 1994). Slide mounts were dried (3-5 days at $60^{\circ} \mathrm{C}$ ) to clarify oil drops and observed with a Zeiss Axioskop compound microscope. Images of glomerospores were taken using a Canon digital camera.

General terminology follows Goto et al. (2008) and Oehl et al. (2011a), and spore terminology follows Goto \& Maia (2006). Holotype and isotype specimens are conserved at the Herbarium of Departamento de Micologia, Universidade Federal de Pernambuco (URM), and other specimens at the Herbarium of Departamento de Botânica, Ecologia e Zoologia, Universidade Federal do Rio Grande do Norte (UFRN).

\section{Arbuscular mycorrhizal cultures}

Cultures of the new species were tentatively established in three institutions, two in Brazil and one in Argentina. For culturing the native AM fungal communities $400 \mathrm{~g}$ of field soil were placed into $500 \mathrm{ml}$ pots at the Departamento de Ciência do Solo, Universidade Federal Rural do Rio de Janeiro (Seropédica, Rio de Janeiro, BR). Brachiaria decumbens was used as bait plant and the culture pots were maintained in the greenhouse. At the Departamento de Micologia, Universidade Federal de Pernambuco (Recife, Pernambuco, BR), cultures were set up using $800 \mathrm{~g}$ of field soil collected from Pernambuco into $1000 \mathrm{~mL}$ pots. Maize (Zea mays), sunflower (Helianthus annuus L.), and sorghum (Sorghum bicolor (L.) Moench) were used as bait plants and the pots were kept in the greenhouse. At the Microbiology Laboratory, EEA INTA Balcarce, Argentina, 
for single species cultures multiple glomerospores were separated from field samples and used as infective propagules using $800 \mathrm{~g}$ of field soil collected from Acre into 1000 $\mathrm{mL}$ pots, with Secale cereale L. as host plant. The cultures were maintained (one year) in the greenhouse. So far, all trials failed to establish a successful symbiosis of the new AMF species either in trap cultures or in the single species cultures.

\section{Taxonomy}

Acaulospora endographis B.T. Goto, sp. nov.

FIGS 1-9

MycoBank MB 564888

Differs from other Acaulospora species by its complex ten-layered spore wall structure with spinose ornamentation in the fourth outer wall layer.

Type: Brazil, Pernambuco State, Goiana, Experimental Station of Itapirema (Instituto Agronômico de Pernambuco), from red-yellow Argissols under Cassava cultivation (Holotype, URM83586; isotypes, URM83586a, URM83586b).

Етумоцоgу: endographis refers to ornamentation similar to pencil imprints in an inner layer of the spore wall.

SPOROCARPs unknown. Acaulosporoid spores form singly in soils upon a short pedicel arising laterally on the tapering hyphal neck of a sporiferous saccule. The glomerospore forms three spore walls - outer wall $(\mathrm{OW})$, middle wall (MW), and inner wall (IW) - with ten layers total.

SPORIFEROUS SACCULE hyaline to white, globose to subglobose and formed terminally on a hypha, generally absent and detached from the mature spore while the pedicel or collar often persists on the glomerospore. The saccule wall is generally bi-layered with a rapidly degrading evanescent hyaline to light yellow outer layer $(0.5-1.5(-2.0) \mu \mathrm{m})$ and semi-persistent hyaline to subhyaline inner layer $0.8-1.5(-2.2) \mu \mathrm{m}$.

Glomerospores form singly on a short hyphal pedicel. The spores are globose $(74-128 \mu \mathrm{m}$ diam.) to subglobose to oval $(68-110 \times 69-100(-180))$, yellow brown to orange brown in water (generally dark orange to dark orange brown in PVLG-based mountants). The spore wall is complex with ten layers distributed in the three walls (OW, MW, IW).

OUTER WALL consists of five layers, with the outermost layer (OWL1) evanescent, $0.5-1.5 \mu \mathrm{m}$ thick, hyaline to sub-hyaline, and often difficult to detect, as it tightly adheres to OWL2. OWL2 is laminated, 2.2-5.4 $\mu \mathrm{m}$ thick, and yellow to orange brown. OWL3 is thin $(<0.5 \mu \mathrm{m})$, hyaline, and tightly attached to OWL2, making it difficult to detect. In older spores, the outer wall layer might degrade completely, but usually some fragments remain on the OWL2 surface. A fourth layer (OWL4) is $2.5-4.5 \mu \mathrm{m}$ thick, yellow to yellow brown and ornamented with spines, generally $0.5-1.0(-1.5) \mu \mathrm{m}$ wide and 1.5-2.0(-2.5) $\mu \mathrm{m}$ high. OWL5 tightly adheres to OWL4 and is flexible, thin $(<1.0 \mu \mathrm{m})$, hyaline and difficult to see. No Melzer's reaction is evident in any outer wall layer. 


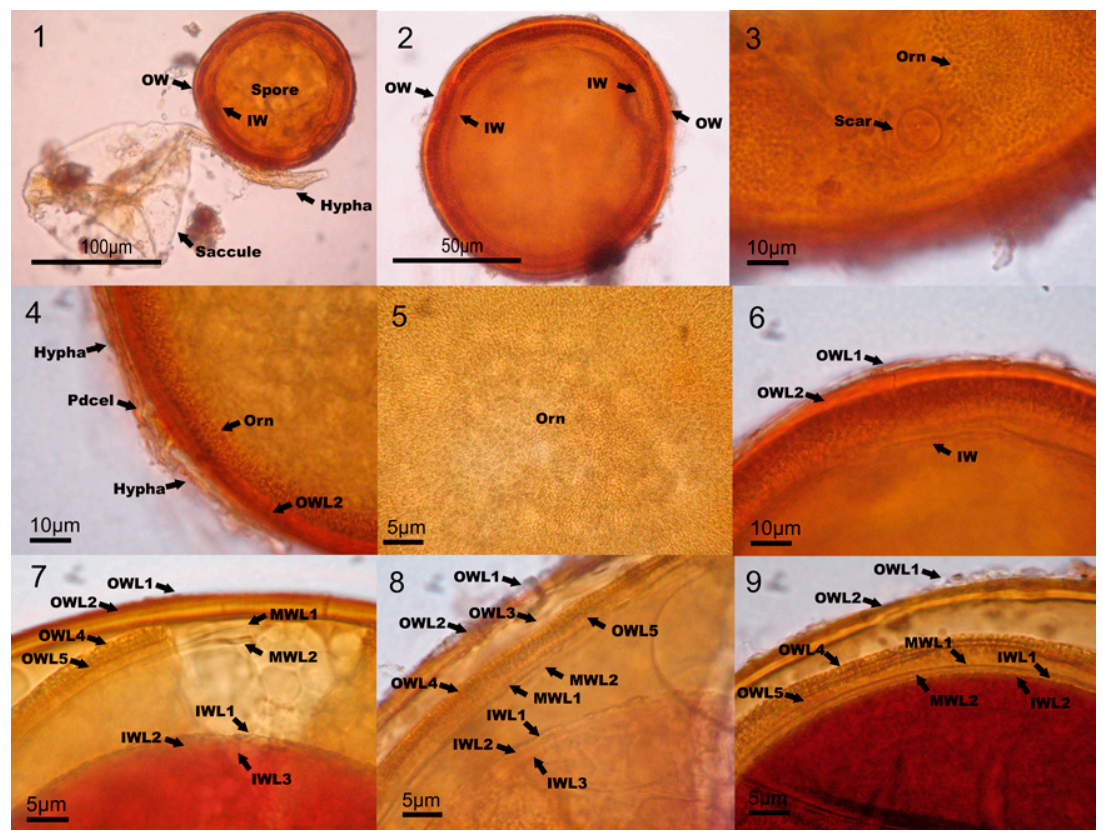

FIGs 1-9. Acaulospora endographis. 1. Young spores with hyaline to sub-hyaline sporiferous saccule attached. 2. Intact glomerospores with distinctive outer wall (ow) and inner wall (Iw). 3. Cicatrix globose to subglobose commonly observed in healthy spores; note the ornamentation (Orn) in a planar view. 4. Insertion point of hypha in spore with a short pedicel (Pdcel). In this case the pedicel wall is continuous with owL1. 5. Ornamentation in a planar view. 6. Spore wall with distinctive outer wall (OW) and inner wall (IW). 7-9. Spore wall structure with OW, middle wall (MW) and IW. Note the outer wall with five layers (owL1,2,3,4,5) and ornamentation in owL4. Inner wall presents a beaded layer (IWL1) and a strong Melzer's reaction.

Middle wall is bi-layered and $2.0-4.0 \mu \mathrm{m}$ thick. MWL1 is semi-rigid to flexible, $1.0-1.5 \mu \mathrm{m}$ thick, hyaline, and tightly adheres to MWL2, also semirigid to flexible, $1.0-2.0 \mu \mathrm{m}$, and hyaline. The bi-layered wall component appears laminated in some spores. No Melzer's reaction is evident in either middle wall layer.

INNER WALL is three-layered, with all three layers hyaline. The outer layer IWL1 is $0.5-1.0 \mu \mathrm{m}$ and easy to detect, ornamented with granular (beaded) projections, and tightly adherent to IWL2 which is amorphous and generally $1.5-3.5 \mu \mathrm{m}$ thick. IWL3 adheres to IWL2 and is thin $(0.5-1.0 \mu \mathrm{m}$ thick) and difficult to see. The Melzer's reaction is dark red purple in IWL2.

Pedicel short, 2-4 $\mu \mathrm{m}$ long, and 4-6(-8) $\mu \mathrm{m}$ wide at the glomerospore base. The wall layer of the pedicel is $3-4 \mu \mathrm{m}$ thick and sub-hyaline to light yellow. The pedicel wall layer is always continuous with the outer spore wall 
layer (OWL1), and the OWL2 sometimes forms a collar on the glomerospore (2.5-4 $\mu \mathrm{m}$ diam.)..

Germination was not observed. The germination structure is believed to resemble those observed in other Acaulospora species (see Spain 1992).

ARBUSCULAR MYCORRHIZA FORMATION is unknown.

Distribution - So far, known only from Brazil in soils from disturbed areas of the Amazon Forest (North Brazil) and in agricultural systems from the Atlantic rainforest (Northeast Brazil).

Additional material examined: BRAZIL, Acre State, Xapuri, Seringal Cachoeira, from red-yellow Argissols (UFRN1742 [permanent slides with PVLG]).

\section{Discussion}

The low number of glomerospores (2-6) in $100 \mathrm{~g}$ of the field soil samples from both sites explains the difficulty in obtaining trap and pure cultures of the new fungus during this study.

Its complex distinct spore wall and ornamentation easily separate Acaulospora endographis from other acaulosporoid species. A similar ornamentation is found only in Entrophospora infrequens (I.R. Hall) R.N. Ames \& R.W. Schneid., but the entrophosporoid spore development and two-walled structure easily distinguish $E$. infrequens from A. endographis. Furthermore, the evanescent or semi-persistent layers covering the ornamentation in E. infrequens (Sieverding \& Oehl 2006, Oehl et al. 2011c) is quite distinct from the permanent rigid laminated layer covering the ornamentation in A. endographis.

The complex 10-layered spore wall structure with one spiny ornamented layer (OWL4) easily distinguishes A. endographis from all other ornamented Acaulospora species.

\section{Acknowledgements}

The authors especially acknowledge Dr. Fabien Hountondji (University of Parakou, Benin) and Dr. Eduardo Furrazola (Instituto de Ecología e Sistemática, IES-CITMA, de la Habana, Cuba) for reviewing the manuscript and making helpful comments and suggestions and appreciate the corrections by Shaun Pennycook, Nomenclatural Editor, and suggestions by Lorelei L. Norvell, Editor-in-Chief. This work was supported by: Protax (Programa Capacitação em Taxonomia), and INCT Herbário Virtual da Flora e dos Fungos, both from the Conselho Nacional de Desenvolvimento Científico e Tecnológico (CNPq) that provided research grants to Ricardo L.L. Berbara and Leonor C. Maia; aid of a grant from the Inter-American Institute for Global Change Research (IAI) CRN 2014 which is supported by the US National Science Foundation (Grant GEO-04523250).

\section{Literature cited}

Brundrett M, Melville L, Peterson L. 1994. Practical methods in mycorrhizal research. University of Guelph, Mycologue Publications, Guelph, Ontario. 
Cuenca G, Herrera-Peraza R. 2008. Scutellospora striata sp. nov., a newly described glomeromycotan fungus from La Gran Sabana, Venezuela. Mycotaxon 105: 79-87.

Goto BT, Maia LC. 2006. Glomerospores: a new denomination for the spores of Glomeromycota, a group molecularly distinct from Zygomycota. Mycotaxon 96: 129-132.

Goto BT, Maia LC, Oehl F. 2008. Ambispora brasiliensis, a new ornamented species in the arbuscular mycorrhiza-forming Glomeromycetes. Mycotaxon 105: 11-18.

Goto BT, Silva GA, Maia LC, Oehl F. 2009. Racocetra intraornata, a new species in the Glomeromycetes with a unique spore wall structure. Mycotaxon 109: 483-491. http://dx.doi.org/10.5248/109.483

Goto BT, Silva GA, Maia LC, Oehl F. 2010. Dentiscutata colliculosa, a new species in the Glomeromycetes from Northeastern Brazil with colliculate spore ornamentation. Nova Hedwigia 90: 383-393. http://dx.doi.org/10.1127/0029-5035/2010/0090-0383

Goto BT, Silva GA, Maia LC, Souza RG, Coyne D, Tchabi A, Lawouin L, Hountondji F, Oehl F. 2011. Racocetra tropicana, a new species in the Glomeromycetes from tropical areas. Nova Hedwigia 92: 69-82. http://dx.doi.org/10.1127/0029-5035/2011/0092-0069

Goto BT, Silva GA, Assis DMA, Silva DKA, Souza RG, Ferreira ACA, Jobim K, Mello CMA, Evangelista-Vieira HE, Maia LC, Oehl F. 2012. Intraornatosporaceae (Gigasporales), a new family with two new genera and two new species. Mycotaxon 119: 117-132. http://dx.doi.org/10.5248/119.117

Oehl F, de Souza FA, Sieverding E. 2008. Revision of Scutellospora and description of five new genera and three new families in the arbuscular mycorrhiza forming Glomeromycetes. Mycotaxon 106: 311-360.

Oehl F, Silva GA, Palenzuela J, Sánchez-Castro I, Castillo C, Sieverding E. 2011a. Acaulospora punctata, a new fungal species in the Glomeromycetes from mountainous altitudes of the Swiss Alps and Chilean Andes. Nova Hedwigia 93:353-362. http://dx.doi.org/10.1127/0029-5035/2011/0093-0353

Oehl F, Sýkorová Z, Błaszkowski J, Sánchez-Castro I, Coyne D, Tchabi A, Lawouin L, Hountondji FCC, Silva GA. 2011b. Acaulospora sieverdingii, an ecologically diverse new fungus in the Glomeromycota, described from lowland temperate Europe and tropical West Africa. J. Appl. Bot. Food Qual. 84: 47-53.

Oehl F, Silva GA, Sánchez-Castro I, Goto BT, Maia LC, Evangelista-Vieira HE, Barea JM, Sieverding E, Palenzuela J. 2011c. Revision of Glomeromycetes with entrophosporoid and glomoid spore formation with three new genera. Mycotaxon 117: 297-316. http://dx.doi.org/10.5248/117.297

Sieverding E. 1991. Vesicular-arbuscular mycorrhiza management in tropical agrosystems. Deutsche Gesellschaft für Technische Zusammenarbeit (GTZ) GmbH, Eschborn, Germany.

Sieverding E, Oehl F. 2006. Revision of Entrophospora and description of Kuklospora and Intraspora, two new genera in the arbuscular mycorrhizal Glomeromycota. J. Appl. Bot. Food Qual. 80: 69-81.

Silva DKA, Freitas NO, Cuenca G, Maia LC, Oehl F. 2008. Scutellospora pernambucana, a new fungal species in the Glomeromycetes with a diagnostic germination orb. Mycotaxon 106: 361-370.

Spain JL. 1992. Patency of shields in water mounted spores of four species in Acaulosporaceae (Glomales). Mycotaxon 43: 331-339.

Tchabi A, Hountoudji F, Laouwin L, Coyne D, Oehl F. 2009. Racocetra beninensis, from sub-saharan savannas: a new species in the Glomeromycetes with ornamented spores. Mycotaxon 110: 199-209. http://dx.doi.org/10.5248/110.199

Vaingankar JD, Rodrigues BF. 2011. Acaulospora soloidea, a new arbuscular mycorrhizal fungus from rhizosphere soils of Murraya paniculata. Mycotaxon 115: 323-326. http://dx.doi.org/10.5248/115.323 